Marquette University

e-Publications@Marquette

4-1-2010

\title{
Are Consumers Disadvantaged or Vulnerable? An Examination of Consumer Complaints to the Better Business Bureau
}

Dennis Garrett

Marquette University, dennis.garrett@marquette.edu

Peter Toumanoff

Marquette University, peter.toumanoff@marquette.edu

Accepted version. Journal of Consumer Affairs, Volume 44, No. 1 (Spring 2010): 3-23. DOI. (C) 2010 John Wiley \& Sons, Inc. Used with permission. 
Marquette University

\section{e-Publications@Marquette}

\section{Economics Faculty Research and Publications/College of Business Administration}

This paper is NOT THE PUBLISHED VERSION; but the author's final, peer-reviewed manuscript.

The published version may be accessed by following the link in the citation below.

Journal of Consumer Affairs, Vol. 44, No. 1, (2010): 3-23. DOI. This article is @ Wiley and permission has been granted for this version to appear in e-Publications@Marquette.Wiley does not grant permission for this article to be further copied/distributed or hosted elsewhere without the express permission from Wiley.

\section{Are Consumers Disadvantaged or Vulnerable? An Examination of Consumer Complaints to the Better Business Bureau}

Dennis E. Garrett

Department of Marketing, Marquette University, Milwaukee, WI

Peter G. Toumanoff

Department of Economics, Marquette University, Milwaukee, WI

\section{Abstract}

Questions have emerged recently about the appropriateness of defining disadvantaged consumers based on their membership in certain demographic categories, such as income, age, education, and race. This study assessed whether these traditional classifications are useful for understanding consumer complaining behavior with the Better Business Bureau. Results of analysis of more than 24,000 consumer complaints filed with a local BBB office during a 13-year period do not provide 
consistent support for this disadvantaged consumer perspective. Instead, the emerging vulnerable consumer perspective may provide a more promising basis for future research.

The Better Business Bureau is the third-party complaint agency most commonly used by dissatisfied consumers who are unable to obtain redress from companies (Best and Andreasen 1977; Duhaime and Ash 1979; Lee and Soberon-Ferrer 1996). In theory, the BBB may be a helpful ally of consumers, particularly those who are most disadvantaged in our society, as they struggle to resolve their complaints with businesses (Fisher et al. 1999). However, many studies over the years have investigated consumer usage of third-party complaint agencies and concluded that these agencies are primarily not used by disadvantaged consumers in our society. Instead, prior research claims to show that younger, nonminority consumers with relatively high incomes and educational levels are more likely to take advantage of services from third-party agencies, like the BBB.

The research of this report takes a new look at the conceptual and methodological challenges involved in analyzing disadvantaged consumer usage of complaint services available through the BBB. Regarding conceptual issues, considerable debate has emerged in recent years regarding the appropriate definition of disadvantaged consumers. Most of the prior research in this area has focused on certain categories of consumers as being disadvantaged due to their age, income, education, or racial/ethnic membership (e.g., Barnhill 1972; Andreasen 1975, 1976, 1993; Stein 1980; Bernhardt 1981; Singh 1989). In sharp contrast, Baker, Gentry, and Rittenburg (2005) have argued strongly that this approach is inappropriate because it suggests that all members in these categories are always at risk as consumers. Instead, they suggest that research should focus on the concept of vulnerable consumers rather than disadvantaged consumers. They assert that any individual consumer, regardless of membership in any particular class, may at various times experience vulnerability in the marketplace.

However, Commuri and Ekici (2008) have recently countered that researchers should still recognize the value of focusing on some categories of consumers as being more likely to be vulnerable than some other categories. They suggest that the traditional disadvantaged consumer conceptualization based on demographic categories may indeed be useful and should not be abandoned. Therefore, this study hopes to shed light on which of these two approaches, disadvantaged consumers or vulnerable consumers, may provide a stronger conceptual foundation for future research.

Beyond these conceptual issues, most research studies in this area have asked consumers to complete mail surveys in which they were instructed to recall a prior unsatisfactory purchase experience and then describe what they did in response to this single episode. This method has potentially serious limitations and leading researchers have long argued that alternative research methods should be used (Andreasen 1988; Singh 1989).

To address these conceptual and methodological issues, this study takes a fresh look at consumer usage of BBB complaint services. Rather than relying on consumers' self-reports of complaint behavior, this study analyzes consumer complaints from a local BBB office and matches the complainants' zip codes with U.S. Census Bureau data regarding the characteristics of consumers in these zip code areas. Because the proportion of potentially disadvantaged consumers varies widely across the zip code areas included in this study, this approach may provide a clearer view of the degree to which certain categories of consumers actually seek redress from the BBB. From our review of prior research of consumer usage of third-party complaints, this appears to be the first time this methodological approach has been used to address these research questions. 
The remainder of this paper is organized as follows. First, the debate regarding disadvantaged versus vulnerable consumers is discussed in more detail. Then prior research of consumer use of the BBB as a third-party complaint agency is reviewed. After that, the research methods used in prior studies are discussed in more detail. Then the specific hypotheses addressed in this study are presented and the methods used to address these hypotheses are explained. Finally, the results of this study are presented and the significance of these findings discussed.

\section{DISADVANTAGED OR VULNERABLE CONSUMERS: CONCEPTUAL ISSUES}

Developing a conceptualization of consumer vulnerability that is widely accepted by researchers has proven to be exceedingly elusive and complex (Andreasen and Manning 1990; Brenkert 1998; Halstead, Jones, and Cox 2007; Mansfield and Pinto 2008). The term "disadvantaged" was commonly used in earlier research studies to describe those categories of consumers who were potentially most at risk in the market. In his seminal book The Disadvantaged Consumer, Andreasen $(\mathbf{1 9 7 5}, \mathbf{7})$ asserted

"The disadvantaged consumer hypothesis argues that the problems of disadvantaged consumers are primarily attributable to their personal characteristics, the kind of people they are. It holds that the real problem is that disadvantaged consumers are just too old, too poor, too uneducated, too unsophisticated, too definitely of the wrong race, etc., to be able to be effective consumers in the urban marketplace."

Following this classification approach, considerable research has focused on the following four demographic variables as being the most definitive markers of a consumer's potential vulnerability in the marketplace:

1. 1 Income: The poor are considered to be vulnerable compared to consumers with higher incomes (Barnhill 1972; Andreasen 1975, 1976, 1988, 1993; Stein 1980; Morgan and Riordan 1983; Kolodinsky et al. 2005).

2. 2 Age: The elderly are considered to be vulnerable because they have more difficulty than younger people navigating the marketplace (Barnhill 1972; Andreasen 1975, 1976, 1988; Morgan and Riordan 1983).

3. 3 Education: Vulnerable consumers include individuals who have received less formal education (Andreasen 1975, 1988, 1993; Smith and Cooper-Martin 1997; Mitra et al. 1999; Ringold 2005).

4. 4 Race and ethnicity: A number of studies have concentrated on the challenges faced primarily by African-American consumers and Hispanic consumers (Andreasen 1975, 1976, 1982, 1988; Stein 1980; Morgan and Riordan 1983; Penaloza 1995; Smith and Cooper-Martin 1997; Crockett, Grier, and Williams 2003; D'Rozario and Williams 2005; Marlowe and Atiles 2005). Minority immigrants with poor English-language skills are included among disadvantaged consumers (Barnhill 1972; Andreasen 1982; Marlowe and Atiles 2005).

More recently, this conceptualization of disadvantaged consumers based on membership in certain demographic categories has been sharply criticized (Ringold 1995, 2005; Baker, Gentry, and Rittenburg 2005). They argue that it is inappropriate because it implies that some consumers are always vulnerable, simply because of their membership in a certain class. Instead, Baker, Gentry, and Rittenburg (2005) assert that a comprehensive, individual-based conceptualization is more robust and is more appropriate for understanding and researching vulnerable consumers: 
"Consumer vulnerability is a state of powerlessness that arises from an imbalance in marketplace interactions or from the consumption of marketing messages and products. It occurs when control is not in an individual's hands, creating a dependence on external factors (e.g., marketers) to create fairness in the marketplace. The actual vulnerability arises from the interaction of individual states, individual characteristics, and external conditions within a context where consumption goals may be hindered and the experience affects personal and social perceptions of self. (p. 134)"

However, their proposed conceptualization of vulnerable consumers has not been met with universal acceptance. Using a macromarketing perspective to defend the traditional definition of disadvantaged consumers, Commuri and Ekici (2008) have argued that this newer conceptualization of consumer vulnerability ignores marketplace realities. They suggest that researchers should acknowledge that unscrupulous marketers may target certain types of consumers and therefore some classes of consumers are more likely than others to be at risk at some point. They propose that "the key, therefore, is to rethink our classification system and capture the relevant classificatory variables but not to abandon a class-based perspective altogether" (p. 185). By better understanding which categories of consumers may be most at risk, they argue that public policy decision makers will be able to proactively establish necessary rules and regulations to protect these groups.

Given this ongoing debate, one of our goals is to determine which of these two opposing conceptualizations, disadvantaged consumers or vulnerable consumers, may be more appropriate for understanding complaining behavior. More specifically, as suggested by Commuri and Ekici (2008), we seek to determine which, if any, classification variables are useful for understanding disadvantaged consumer usage of the BBB. The next section reviews prior empirical research regarding the complaining behavior of disadvantaged and vulnerable consumers.

\section{COMPLAINING BEHAVIOR OF DISADVANTAGED AND VULNERABLE CONSUMERS}

Disadvantaged or vulnerable consumers may potentially be affected at various stages of the consumption process. In the beginning of the buying process consumers may lack the skills, education, literacy or experience to gather the requisite information to evaluate the relative quality of competitive products and vendors in the market (Barnhill 1972; Andreasen 1975; Marlowe and Atiles 2005; Adkins and Ozanne 2005a). In addition, due primarily to their lower incomes, they may lack the mobility to travel to shop at more attractive and desirable stores (Andreasen 1976, 1993; Stein 1980). When they do interact with salespeople, they may face discriminatory practices, higher prices and lower levels of customer service (Andreasen 1976, 1982; Stein 1980; Crockett, Grier, and Williams 2003). Finally, if they do experience an unsatisfactory purchase, disadvantaged consumers may lack the resources needed to seek appropriate redress (Andreasen 1975, 1976).

This last stage in the consumption process, seeking redress for an unsatisfactory purchase, is of particular interest in this study. In their earlier review of research in this area, Andreasen and Manning $(1990,14)$ noted, "Despite the fact that vulnerable consumers often have more to lose if something goes wrong with a purchase, they seem less likely than other consumers to do something about it." Similarly, Halstead, Jones, and Cox (2007) recently concluded from their qualitative research that disadvantaged consumers often fail to complain when they are dissatisfied. This apparent reticence on 
the part of disadvantaged or vulnerable consumers to complain is troubling. One would hope that those consumers who are most at risk and have the most to lose from their dissatisfying purchase experiences would actually be more inclined to push forward with their complaints.

The BBB, with 125 local offices throughout the United States and Canada, plays a potentially pivotal role in the consumer complaining behavior process, especially as it relates to disadvantaged or vulnerable consumers. Although consumers may now choose to express their dissatisfaction against companies in online forums (Cho et al. 2002; Ward and Ostrom 2006), the BBB has maintained its relevance, as the number of consumer complaints filed with the BBB increased from 626,081 in 2002 to 862,128 in 2008. The BBB strongly encourages dissatisfied consumers to contact companies directly, but the BBB will accept consumer complaints even if this step is not taken. Therefore, for disadvantaged or vulnerable consumers who are either unwilling to seek or unable to achieve resolution for their complaints from companies, the BBB offers a viable option for them to pursue.

However, do disadvantaged or vulnerable consumers actually take advantage of the complaint services offered by the BBB? Not surprisingly, this important question has attracted considerable research attention over the past few decades. Because the bulk of this research has adopted the category-based conceptualization of disadvantaged consumers, this review is organized on the leading classification variables of income, age, education, and minority status, as shown in Table 1.

Table 1. Disadvantaged Consumer Complaining Behavior Literature Review

\begin{tabular}{|c|c|c|c|}
\hline $\begin{array}{l}\text { Disadvantaged } \\
\text { Variable }\end{array}$ & $\begin{array}{l}\text { Type of } \\
\text { Complaining }\end{array}$ & $\begin{array}{l}\text { Disadvantaged } \\
\text { Consumers } \\
\text { Complain More }\end{array}$ & Disadvantaged Consumers Complain Less \\
\hline Income & $\begin{array}{l}\text { General } \\
\text { complaining }\end{array}$ & & $\begin{array}{l}\text { Andreasen (1988); Bearden } \\
\text { (1983); Francken and van Raaij } \\
\text { (1985); Liefeld, Edgecombe, and Wolfe } \\
\text { (1975); Morgansky and Buckley } \\
\text { (1987); Moyer (1984); TARP (1986); Volkov, } \\
\text { Harker, and Harker (2005) }\end{array}$ \\
\hline Income & $\begin{array}{l}\text { Third-party } \\
\text { complaining }\end{array}$ & Hogarth et al. (2001) & $\begin{array}{l}\text { Andreasen (1988); Duhaime and Ash } \\
\text { (1979); Hogarth, English, and Sharma } \\
\text { (2001); Liefeld, Edgecombe, and Wolfe } \\
\text { (1975); Singh (1989); Volkov, Harker, and } \\
\text { Harker (2005) }\end{array}$ \\
\hline Age & $\begin{array}{l}\text { General } \\
\text { complaining }\end{array}$ & $\begin{array}{l}\text { Lee and Soberon- } \\
\text { Ferrer (1996) }\end{array}$ & $\begin{array}{l}\text { Andreasen (1988); Bearden (1983); Liefeld, } \\
\text { Edgecombe, and Wolfe (1975); Moyer } \\
\text { (1984); Singh (1989); TARP } \\
\text { (1986); Warland, Herrmann, and Moore } \\
\text { (1984) }\end{array}$ \\
\hline Age & $\begin{array}{l}\text { Third-party } \\
\text { complaining }\end{array}$ & $\begin{array}{l}\text { Bernhardt } \\
\text { (1981); Hogarth, } \\
\text { English, and Sharma } \\
\text { (2001) }\end{array}$ & $\begin{array}{l}\text { Andreasen (1988); Duhaime and Ash } \\
\text { (1979); Hogarth et al. (2001); Liefeld, } \\
\text { Edgecombe, and Wolfe (1975); Singh } \\
\text { (1989) }\end{array}$ \\
\hline Education & $\begin{array}{l}\text { General } \\
\text { complaining }\end{array}$ & & $\begin{array}{l}\text { Andreasen (1988); Huefner and Hunt } \\
\text { (2000); Kolodinsky (1993); Lee and } \\
\text { Soberon-Ferrer (1996); Liefeld, Edgecombe, }\end{array}$ \\
\hline
\end{tabular}




\begin{tabular}{|l|l|l|l|}
\hline & & $\begin{array}{l}\text { and Wolfe (1975); Morgansky and Buckley } \\
\text { (1987); Moyer (1984); Volkov, Harker, and } \\
\text { Harker (2005); Warland, Herrmann, and } \\
\text { Moore (1984) }\end{array}$ \\
\hline Education & $\begin{array}{l}\text { Third-party } \\
\text { complaining }\end{array}$ & $\begin{array}{l}\text { Hogarth et al. } \\
\text { (2001); Singh (1989) }\end{array}$ & $\begin{array}{l}\text { Andreasen (1988); Bearden (1983); Best } \\
\text { and Andreasen (1977); Duhaime and Ash } \\
\text { (1979); Lee and Soberon-Ferrer } \\
\text { (1996); Liefeld, Edgecombe, and Wolfe } \\
\text { (1975); Volkov, Harker, and Harker (2005) }\end{array}$ \\
\hline Race & $\begin{array}{l}\text { General } \\
\text { complaining* }\end{array}$ & $\begin{array}{l}\text { Andreasen (1988); Best and Andreasen } \\
\text { (1977); Villareal-Camacho (1983) }\end{array}$ \\
\hline Race & Third-party & $\begin{array}{l}\text { Hogarth, English, } \\
\text { and Sharma } \\
\text { (2001); Hogarth et } \\
\text { al. (2001) }\end{array}$ & \\
\hline
\end{tabular}

${ }^{*}$ TARP (1986) finds no difference between disadvantaged consumers and general population.

\section{Income}

In general, the research regarding the relationship between a consumer's income and his/her subsequent complaining behavior is quite consistent. A number of prior studies have shown that lowerincome consumers are less likely than higher-income consumers to engage in any form of complaining behavior. Similarly, most previous research has also shown that lower-income consumers are less likely than higher-income consumers to seek assistance from third-party agencies. The one exception is a study by Hogarth et al. (2001)_that concluded that lower-income consumers were more likely to use third-party agencies.

\section{Age}

The research regarding the impact of age on complaining behavior is also fairly consistent. Most prior studies have shown that older consumers are generally less likely than younger consumers to complain about their dissatisfaction. Regarding the specific use of third-party complaint agents, older consumers are also reportedly less likely than younger consumers to pursue this option, according to the results of most studies. However, studies by Bernhardt (1981) and Hogarth, English, and Sharma (2001) found that older consumers were more likely than younger consumers to use third-party agencies.

\section{Education}

Consumers with less formal education appear to be less likely to complain than do more highly educated consumers. Although most studies have reported that less-educated consumers were less likely to pursue third-party actions, two studies have concluded that less-educated consumers were actually more likely to be third-party complainers (Singh 1989; Hogarth et al. 2001).

\section{Minority Consumers}

TARP (1986) reported that race does not affect the likelihood of a consumer filing a complaint. However, Best and Andreasen (1977), Villareal-Camacho (1983), and Andreasen (1988) argued that minority consumers are less likely to complain. In terms of third-party agent usage, recent research has reported that minority consumers are actually more likely than nonminority consumers to use thirdparty agents for their complaints (Hogarth, English, and Sharma 2001; Hogarth et al. 2001). 
Also, Cornwell, Bligh, and Babakus (1991) concluded that the English-language ability of Hispanic consumers apparently does not inhibit their ability to file complaints with the BBB.

Because the studies by Hogarth, English, and Sharma (2001) and Hogarth et al. (2001)_reported consistently different results from most other studies, their research foci and methods deserve further attention. Hogarth, English, and Sharma (2001) analyzed consumer complaints filed with the U.S. Federal Reserve complaint program. They collected data on consumer attitudes and behaviors by contacting consumers who had recently had their complaint cases closed and asking them to complete a mail questionnaire. Again working with the Federal Reserve, Hogarth et al. (2001) analyzed consumer problems with credit cards by conducting telephone interviews, including detailed follow up questions regarding how consumers dealt with their complaints. Although these studies focused specifically on consumer problems with financial services, it is not immediately clear why these studies reported results so different from the bulk of previous research in this area.

In summary, prior research generally appears to provide support for the hypothesis that disadvantaged consumers are less likely to complain, including the use of third-party complaint agencies. However, as the next section details, serious concerns have been raised regarding the methods used in these research studies. Because this prior research relies heavily on self-reported data regarding complaining behavior, a different method of collecting data may help to clarify the current debate between proponents of the disadvantaged consumer perspective and the vulnerable consumer perspective.

\section{PREVIOUS RESEARCH METHODS}

Research regarding the demographic characteristics of complaining consumers has relied mainly on surveys (primarily by mail) in which respondents are asked to recall a single previous purchase that was unsatisfactory and then describe what actions they took (e.g., Liefeld, Edgecombe, and Wolfe 1975; Day and Landon 1977; Warland, Herrmann, and Moore 1984; Francken and van Raaij 1985; TARP 1986; Gronhaug 1987; Singh 1988, 1989, 1991; Kolodinsky 1993, 1995). This practice may create issues because it is uncertain which types of prior purchases consumers will choose to focus on when they respond. Because of this limitation, Andreasen $(\mathbf{1 9 8 8 , 7 0 2 )}$ argued, "If we are to avoid confounding our findings about how often consumers complain, who complains and in what manner, we must not permit consumers the freedom to choose the occasion of dissatisfaction we will explore" (emphasis included in original). This approach may be further limited because of respondents' recall and memory abilities, especially for episodes that may have occurred several months earlier (Singh 1989).

In addition, this use of consumer surveys may be problematic when the research focus is specifically on third-party complaining behavior. It is generally accepted that consumers engage in third-party complaining behavior in fewer than $10 \%$ of unsatisfactory purchase experiences (TARP 1986; Andreasen 1988; Fisher et al. 1999; Garrett 2004). Because third-party complaints tend to be "needles in haystacks," most prior studies using consumer surveys have identified and analyzed very small numbers of relevant cases of third-party complaining behavior, which has limited the robustness of their results (Andreasen and Best 1977; Best and Andreasen 1977; Day and Landon 1977; Moyer 1984; Singh 1991; Kolodinsky 1993; Hogarth et al. 2001).

Therefore, the use of alternative research methods to examine consumer usage of third-party complaint agencies may add valuable insight. In the next section, the hypotheses evaluated in this study are presented, followed by a discussion of the methodology used in this study. 


\section{HYPOTHESES}

The following hypotheses evaluate whether disadvantaged consumer usage of BBB complaint services is indeed a function of the four dominant demographic characteristics proposed in prior research:

"H1: Consumers with lower incomes are significantly less likely to complain to the BBB than consumers with higher incomes.

$\mathrm{H} 2$ : Older consumers are significantly less likely to complain to the BBB than younger consumers.

H3: Consumers with less formal education are significantly less likely to complain to the BBB than consumers with more formal education.

H4: Consumers from minority backgrounds are significantly less likely to complain to the BBB than consumers from nonminority backgrounds."

We have stated these hypotheses in the manner implied by the disadvantaged consumer perspective. Therefore, to the extent that our study accepts or rejects these null hypotheses, the disadvantaged consumer perspective is supported or rejected.

\section{METHOD}

As noted above, most prior research in this area has used mail surveys of consumers and asked them to recall the actions they took in response to a single unsatisfactory purchase. To address the limitations inherent in the methods used in these earlier studies, this study used an alternative approach that has not been previously employed in this area.

\section{Data}

With the cooperation of the BBB office serving Wisconsin, the complete record of complaints filed with this office during a 13-year period (1994-2006) was obtained. The BBB recorded complaints by zip code address of the complainant. The BBB collected 24,256 complaints from 175 zip code areas in 11 counties in southeast Wisconsin. Milwaukee is the largest city in this geographic area and, based on U.S. Census data, is the most segregated city in the United States (Milwaukee Is Most Segregated City 2002). For this reason, this provides a very appropriate setting for this research, particularly in terms of the high variation in minority membership in various zip codes. Twelve of these zip codes were dropped from this analysis because of their small population size (less than 500) and inherent sensitivity to minor changes in number of BBB complaints, leaving a total of 24,153 complaints in the final database registered from 163 zip code areas.

Economic and demographic data for the census year 2000 are also available at the zip code level from the U.S. Census Department. We include variables that represent the categories of disadvantaged consumers: income, age, education, and minority status. We also include variables to account for gender and whether or not the zip code is within major city limits. We did this to avoid omitted variable bias because there is reason to believe that these attributes may affect complaining behavior.

These variables and their mean values are described in Table 2. Because these data do not rely on consumer surveys and self-selected complaints, this research does not suffer from nonresponse or selfselection bias, and the limitations of imperfect memory. However, it is important to note that our sample has its own limitations, which we have acknowledged and addressed whenever possible. Our 
unit of observation is the zip code from which complaints are made, not the individual complainant. Thus, our data do not directly link complaints to consumers with particular demographic and economic characteristics. Instead, we have average numbers of complaints from particular zip codes and these are correlated with the average demographic and economic characteristics of the populations of these zip codes.

Table 2. Variable Descriptions, Means, and Ranges *

\begin{tabular}{|c|c|c|}
\hline Variable and Description & $\begin{array}{l}\text { Mean } \\
\text { Value }\end{array}$ & Range \\
\hline COMPLAINTSPC & 0.012 & $0.0012-0.024$ \\
\hline \multicolumn{3}{|l|}{ Ratio of BBB complaints to population $(\geq 18)$} \\
\hline HHINCPC & 19.66 & $5.18-33.80$ \\
\hline \multicolumn{3}{|l|}{ Median household income/household size (in thousands of dollars) } \\
\hline OVER65 & 36.5 & $22.2-46.1$ \\
\hline \multicolumn{3}{|l|}{ Proportion of population $\geq 65$} \\
\hline COLLEGE & 0.19 & $0.012-0.61$ \\
\hline \multicolumn{3}{|l|}{ Proportion of college graduates in population $(\geq 18)$} \\
\hline HS & 0.56 & $0.21-0.72$ \\
\hline \multicolumn{3}{|l|}{ Proportion of high school graduates in population not included in COLLEGE } \\
\hline ASIAN & 0.01 & $0-0.085$ \\
\hline \multicolumn{3}{|l|}{ Proportion of population of Asian ethnicity } \\
\hline BLACK & 0.06 & $0-0.96$ \\
\hline \multicolumn{3}{|l|}{ Proportion of population of black ethnicity } \\
\hline HISPANIC & 0.036 & $0-0.65$ \\
\hline \multicolumn{3}{|l|}{ Proportion of population of Hispanic ethnicity } \\
\hline ESL & 0.063 & $0.012-0.54$ \\
\hline \multicolumn{3}{|l|}{ Proportion of population that speaks language other than English at home } \\
\hline FEMALE & 0.50 & $0.34-0.55$ \\
\hline \multicolumn{3}{|l|}{ Proportion of population that is female } \\
\hline \multicolumn{3}{|l|}{ CITY } \\
\hline $\begin{array}{l}\text { Zip codes within the city limits of Milwaukee, Kenosha, Racine (binary } \\
\text { variable) }\end{array}$ & 0.23 & $0-1$ \\
\hline
\end{tabular}

*Source of complaints data: Wisconsin Better Business Bureau. Economic and demographic data are from the U.S. Department of the Census.

Also, our dependent variable is the number of complaints made over a 13-year period, whereas our census data are for the year 2000 , the median year of the period over which complaints were made. This could lead to inaccurate results if the economic and demographic characteristics of the zip codes varied systematically over the 13 years. To cross check this possibility, we were able to extract and analyze the complaint data for a more recent three-year period (2003-2005). Using these data from this three-year period does not yield substantially different results of the estimation that was derived from data for the 13-year period.

Although southeastern Wisconsin has relatively low populations of ethnic minorities, there is a high degree of variation in the numbers of these populations across zip codes. Thus, we believe our sample can accurately capture the effects of minority status on complaining behavior. Another potential 
problem with our sample is the possibility of multicollinearity between income and the other variables. Although this does not bias our estimates, it may increase the standard errors of the coefficients. Multicollinearity may be responsible for estimated coefficients that are statistically insignificant.

\section{Empirical Model}

Ordinary Least Squares is used to estimate the following multiple regression model in which BBB complaints per population age 18 and older is the dependent variable:

\section{COMPLAINTSPC $=\mathrm{a}_{0}+\mathrm{a}_{1}$ HHINCPC $+\mathrm{a}_{2}$ PCTOVER65$$
+\mathrm{a}_{3} \mathrm{HS}+\mathrm{a}_{4} \text { COLLEGE }+\mathrm{a}_{5} \text { ASIAN }
$$$$
+\mathrm{a}_{6} \mathrm{BLACK}+\mathrm{a}_{7} \mathrm{HISP}+\mathrm{a}_{8} \mathrm{ESL}
$$$$
+\mathrm{a}_{9} \text { FEMALE }+\mathrm{a}_{10} \text { CITY }+ \text { ERROR }
$$

We have hypothesized that BBB complaints increase with income, so we expect a positive coefficient on household income per capita (HHINCPC). Older and less-educated consumers are considered to be disadvantaged relative to younger and better-educated consumers. Therefore, we expect a negative coefficient to be associated with PCTOVER65, and positive coefficients associated with COLLEGE and HS. Three different types of minority status are measured, accounting for ethnicity. Each is presumed to disadvantage a consumer, so negative coefficients are expected for ASIAN, BLACK, and HISP. We include ESL to separate the effects of ethnicity from possible language barriers. These hypotheses can all be tested with one-tailed $t$-tests. In addition, the two education variables and the four ethnicity variables can be tested for joint significance.

Because previous research has been mixed regarding the relationship between gender and complaint behavior, the percentage of females (FEMALE) in the population is included as an independent variable (see Duhaime and Ash 1979; Stahle and Day 1984; Tipper 1997; Hogarth, English, and Sharma 2001). We also included a dummy variable (CITY) that distinguishes zip codes in urban counties from rural counties to account for differences in access and/or attitude between urban and rural households. Zip codes in the cities of Milwaukee, Racine, and Kenosha (the three major cities in this area) were defined as urban areas and included 38 of the 163 (23\%) zip code areas in the final analysis. Even though these variables do not represent categories of disadvantaged consumers, we include them to avoid omitted variable bias in our results.

\section{RESULTS}

Results of the regression estimate are presented in Table 3. They are considerably at odds with our research hypotheses and the prior research on disadvantaged consumers' complaint behavior.

Table 3. Estimated Regression Coefficients and t-statistics a

\begin{tabular}{|l|l|l|l|}
\hline Independent Variable & Expected Coefficient & Estimated Coefficient & t-Statistic \\
\hline Dependent variable: COMPLAINTSPC & & & \\
\hline CONSTANT & & -0.034 & $-5.91^{* *}$ \\
\hline HHINCPC & Positive & 0.00094 & $4.62^{* *}$ \\
\hline OVER65 & Negative & -0.0084 & -0.87 \\
\hline COLLEGE & Positive & -0.0031 & -0.35 \\
\hline
\end{tabular}




\begin{tabular}{|l|l|l|l|}
\hline HS & Positive & 0.017 & $2.74^{* *}$ \\
\hline ASIAN & Negative & 0.059 & 1.74 \\
\hline BLACK & Negative & 0.015 & $5.94^{* *}$ \\
\hline HISPANIC & Negative & -0.017 & -0.72 \\
\hline ESL & Negative & 0.033 & 1.51 \\
\hline FEMALE & & 0.034 & $2.72^{* *}$ \\
\hline CITY & & 0.0047 & $4.40^{* *}$ \\
\hline No. of observations & & 163 & \\
\hline Adjusted $R^{2}$ & & 0.53 & \\
\hline
\end{tabular}

${ }^{*}$ Sig. $<.05 ;{ }^{* *}$ Sig. $<.01$.

${ }^{a}$ Note that $t$-statistics are calculated with heteroscedasticity-corrected standard errors (White method).

$\mathrm{H} 1$ (Income): As predicted, there is a significantly positive relationship between average household income and average BBB complaints per zip code.

H2 (Age): Contrary to the hypothesis that older consumers would file fewer BBB complaints than younger consumers, the results did not show any significant relationship between average age and average number of BBB complaints per zip code. We tried several different measures of age, including median age, natural log of median age, and both median age and OVER65 together. Our results were not sensitive to alternative measures of age. The correlation coefficient between HHINCPC and OVER65 is only 0.21 , so multicollinearity is not likely to be responsible for this insignificant coefficient.

H3 (Education): Although prior research has generally shown that more highly educated consumers are more likely to file complaints with the BBB, our results revealed that this is only the case for high school graduates who do not have a higher degree. The effect of having a college degree is negative but insignificant. Because income and having a college degree are highly correlated, multicollinearity may be responsible for the insignificant coefficient (although not the negative sign).

H4 (Minority status): Again, our results are contrary to much of the earlier research that argued minority consumers are less likely to file third-party complaints. Our results showed a significantly positive relationship between the percentage of black consumers and average number of BBB complaints per zip code. For ASIAN and HISP and ESL, there was no significant relationship with BBB complaints per zip code. Only ASIAN and BLACK are substantially correlated with HHINCPC (-0.41 and -0.59 , respectively), although ASIAN and HISP are highly correlated with ESL, possibly decreasing the significance of their coefficients.

Finally, our results found a significantly positive relationship between the percentage of female consumers and average number of BBB complaints per zip code and also for city zip codes and BBB complaints. The joint significance tests reported in Table 4 indicate that the education variables are jointly significant, as are the ethnicity variables, indicating that these variables are 
important in explaining complaining behavior, but not necessarily in the way expected by the disadvantaged consumer hypothesis.

Table 4. Joint Significance Tests

\begin{tabular}{|l|l|}
\hline Null Hypothesis & F-statistic \\
\hline $\mathrm{a}_{3}=\mathrm{a}_{4}=0$ & $F(2,153)=9.85^{* *}$ \\
\hline $\mathrm{a}_{5}=\mathrm{a}_{6}=\mathrm{a}_{7}=\mathrm{a}_{8}=0$ & $F(4,153)=15.5^{* *}$ \\
\hline
\end{tabular}

${ }^{* *}$ Sig. $<.01$.

\section{DISCUSSION}

Clearly, these results differ from the bulk of prior studies in this area of disadvantaged consumer complaining behavior. Prior research had suggested that disadvantaged consumer status was based on four variables: income, age, education, and minority status. However, our results did not provide consistent support for this disadvantaged consumer perspective.

Although income and high school graduation rates had a significantly positive relationship with BBB complaining behavior, as suggested by the disadvantaged consumer perspective, most of the other variables (age, college graduation rates, Asian minority status, Hispanic minority status, and English as a second language) were not significantly related to BBB complaints. In addition, contrary to the disadvantaged consumer perspective, our results showed that the percentage of black consumers was significantly and positively related to BBB complaints.

We believe it is possible that income is the primary determinant of complaining behavior, and when it is accounted for, age, lack of a college education, and minority status do not inhibit a consumer's propensity to complain. The fact that income is negatively correlated with lesseducated, elderly, and minority populations may have led previous research to a conclusion that these variables also depress complaints. For those proponents of the disadvantaged consumer perspective, like Commuri and Ekici (2008), who have argued that research should identify the most useful categorical descriptors, it appears that income is the most promising candidate among these demographic variables.

More broadly however, these results shed light on the current debate regarding the comparative utility of the disadvantaged consumer perspective versus the vulnerable consumer perspective. In recent years advocates of the vulnerable consumer perspective have asserted that the conceptualization of disadvantaged consumers is flawed due to its fundamental notion that consumers in certain demographic categories are always at risk in the marketplace (Brenkert 1998; Baker, Gentry, and Rittenburg 2005; Ringold 2005). Instead, they argue that any consumer may potentially experience vulnerability in the marketplace at various times. Our results suggest that the vulnerable consumer framework may indeed be a more useful theoretical perspective than the disadvantaged consumer framework for future research regarding use of third-party complaint agencies. Future research needs to move beyond the overly restrictive demographic categories of income, age, education, and minority status to 
investigate more deeply how and why consumers may experience vulnerability in the marketplace.

Baker, Gentry, and Rittenburg (2005) have provided an excellent conceptual framework to guide future research from the vulnerable consumer perspective. Following their lead, a number of recent studies offer intriguing insights into the multifaceted nature of vulnerable consumer behavior. For instance, the challenges encountered by low-literate consumers in our economy have received attention (Viswanathan, Rosa, and Harris 2005; Adkins and Ozanne 2005a, 2005b; Jae, Delvecchio, and Cowles 2008). This research has focused primarily on understanding how low-literate consumers process advertising messages and develop coping mechanisms for purchasing products in the marketplace. Similarly, recent research has also addressed issues pertaining to health literacy of consumers (Adkins and Corus

2009; McCormack et al. 2009). Overall, this research has shown that consumers with low levels of literacy may experience vulnerability in the marketplace. Given the complexity of these literacy-related issues, the vulnerable consumer framework proposed by Baker, Gentry, and Rittenburg (2005) appears to offer more promise than the restrictive disadvantaged consumer perspective that has dominated earlier research.

The unexpected result showing a significantly positive relationship between black consumers and BBB complaints is noteworthy. If an optimistic perspective is taken, this result could suggest that black consumers have become more assertive in our business culture and do complain to the BBB to seek redress for their dissatisfaction. But from a more pessimistic view, this heightened use of the BBB by black consumers may also indicate that businesses continue to deliver substandard services to these minority consumers and fail to address their subsequent complaints. It may be tempting to delve further into this relationship between consumers' racial backgrounds and their BBB complaining behavior to determine why we found a significantly positive relationship between black consumers and BBB complaints, but no significant relationship for Hispanic and Asian consumers. However, as our society becomes increasingly multiracial, these restrictive demographic categories that have dominated prior consumer complaining research may no longer be that relevant. Instead, we should realize that any consumer, regardless of their racial minority status, may periodically experience vulnerability in the marketplace.

The role of urban versus rural location may warrant further exploration. Our results found that consumers in city locations were significantly more likely to use BBB complaint services than their rural counterparts. This may be due to rural consumers having closer personal ties to the businesses that they patronize and therefore more likely to know which companies are known for good customer service. Similarly, in more rural areas dominated by small towns, negative word-of-mouth communication among close-knit neighbors may help to regulate unscrupulous business owners. Or perhaps city dwellers have become more accustomed to using quasigovernmental systems in their lives and therefore are more willing to use the complaint 
services offered by the BBB. In any case, this intriguing finding deserves more research in the future.

One of the most important implications is that the methodology by which data are collected matters. This was the first attempt to analyze a large number of BBB complaints collected directly from the organization's records. Our findings, which were strikingly different from results from previous research in this area, give credence to the warnings issued over the years from leading researchers like Andreasen (1988) and Singh (1989). They cautioned that research based on asking consumers to report what they did in response to a single, self-selected unsatisfactory consumption experience may be problematic. More research is clearly warranted in this area. In particular, replicating the current research study using data from a different BBB bureau would be instructive, as would analysis of complaint data from alternative third-party complaint agencies other than the BBB.

If future research does adopt the vulnerable consumer framework in favor of the disadvantaged consumer approach, new methodological techniques will be required. The methods used in this study are very appropriate for research based on the disadvantaged consumer framework with its emphasis on demographic consumer descriptors. However, these same methods will not be applicable for conducting research regarding third-party complaint behavior of vulnerable consumers. Instead, research may need to adopt more qualitative techniques, such as those used recently for understanding low-literate consumers (Viswanathan, Rosa, and Harris 2005; Adkins and Ozanne 2005a, 2005b; Adkins and Corus 2009).

\section{CONCLUSION}

We have attempted to shed new light on a very important issue. Namely, do the traditional demographic categories of age, education, income, and race from the disadvantaged consumer framework really help to explain why consumers may or may not express their complaints to third-party complaint agencies like the BBB? Simply stated, the results suggest not. Of these four descriptive consumer variables, only income was significantly and positively related to the frequency of third-party consumer complaints.

These results add support for a movement away from the rather simplistic structure of the disadvantaged consumer perspective in favor of the more comprehensive vulnerable consumer perspective. Our quest should be to determine when and why consumers experience vulnerability in the marketplace. In particular, as we addressed in this study, we should strive to explain how vulnerable consumers respond when they are dissatisfied with their purchases. Ultimately, our goal should be to educate and empower vulnerable consumers so that they seek redress for their complaints from companies, or if that fails, from third-party complaint agencies like the BBB. 
This also offers some valuable insights into the role that alternative research methods may play in our drive to understand the nature of consumer vulnerability. Decades of disadvantaged consumer research primarily relied on surveys of self-reported consumer complaint behavior, which yielded seemingly consistent results. However, we studied consumer complaint behavior by analyzing the frequency of BBB complaints by zip codes and found strikingly different results, suggesting that the use of alternative methods should be encouraged in future research so that a clearer view of the true nature of consumer vulnerability may be obtained.

\section{REFERENCES}

Adkins, Natalie Ross and Canan Corus. 2009. Health Literacy for Improved Health Outcomes: Effective Capital in the Marketplace. Journal of Consumer Affairs, 43 (Summer): 199-222.

Adkins, Natalie Ross and Julie L. Ozanne. 2005a. Critical Consumer Education: Empowering the LowLiterate Consumer. Journal of Macromarketing, 25 (December): 153-162.

Adkins, Natalie Ross and Julie L. Ozanne. 2005b. The Low Literate Consumer. Journal of Consumer Research, 32 (June): 93-105.

Andreasen, Alan R. 1988. Consumer Complaints and Redress: What We Know and What We Don't Know. In The Frontier of Research in the Consumer Interest, edited by E. Scott Maynes (675-722). Columbia, MO: American Council on Consumer Interests.

Andreasen, Alan R.. 1976. The Differing Nature of Consumerism in the Ghetto. Journal of Consumer Affairs, 10 (Winter): 179-190.

Andreasen, Alan R.. 1975. The Disadvantaged Consumer. New York: The Free Press.

Andreasen, Alan R.. 1982. Disadvantaged Hispanic Consumers: A Research Perspective and Agenda. Journal of Consumer Affairs, 16 (Summer): 46-61.

Andreasen, Alan R.. 1993. Revisiting the Disadvantaged: Old Lessons and New Problems. Journal of Public Policy \& Marketing, 12 (Fall): 270-276.

Andreasen, Alan R. and Arthur Best. 1977. Consumers Complain-Does Business Respond?Harvard Business Review, July-August: 93-101.

Andreasen, Alan R. and Jean Manning. 1990. The Dissatisfaction and Complaining Behavior of Vulnerable Consumers. Journal of Consumer Satisfaction, Dissatisfaction and Complaining Behavior, 3: 1220.

Baker, Stacey Menzel, James W. Gentry, and Terri L. Rittenburg. 2005. Building Understanding of the Domain of Consumer Vulnerability. Journal of Macromarketing, 25 (December): 128-139.

Barnhill, J.A. 1972. Market Injustice: The Case of the Disadvantaged Consumer. Journal of Consumer Affairs, 6 (Summer): 78-83.

Bearden, William O. 1983. Profiling Consumers Who Register Complaints Against Auto Repair Services. Journal of Consumer Affairs, 17 (Winter): 315-335.

Bernhardt, Kenneth L. 1981. Consumer Problems and Complaint Actions of Older Americans: A National View. Journal of Retailing, 57 (Fall): 107-123.

Best, Arthur and Alan R. Andreasen. 1977. Consumer Response to Unsatisfactory Purchases: A Survey of Perceiving Defects, Voicing Complaints, and Obtaining Redress. Law and Society Review, 11 (4): 701-742.

Brenkert, George G. 1998. Marketing and the Vulnerable. Business Ethics Quarterly, 7-20. 
Cho, Yooncheong, II Im, Roxanne Hiltz, and Jerry Fjermestad. 2002. The Effects of Post-Purchase Evaluation Factors on Online vs. Offline Customer Complaining Behavior: Implications for Customer Loyalty. Advances in Consumer Research, 29: 318-325.

Commuri, Suraj and Ahmet Ekici. 2008. An Enlargement of the Notion of Consumer Vulnerability.Journal of Macromarketing. 28 (June): 183-186.

Cornwell, T. Bettina, Alan David Bligh, and Emin Babakus. 1991. Complaint Behavior of MexicanAmerican Consumers to a Third-Party Agency. Journal of Consumer Affairs, 25 (Summer): 1-18.

Crockett, David, Sonya A. Grier, and Jacqueline A. Williams. 2003. Coping with Marketplace Discrimination: An Exploration of the Experiences of Black Men. Academy of Marketing Science Review, 2003 (4): 1-18.

D’Rozario, Denver and Jerome D. Williams. 2005. Retail Redlining: Definition, Theory, Typology, and Measurement. Journal of Macromarketing, 25 (2): 175-186.

Day, Ralph L. and E. Laird Landon, Jr. 1977. Toward a Theory of Consumer Complaining Behavior. In Consumer and Industrial Buying Behavior, edited by A. Woodside, J. Sheth, and P. Bennett (425-437). Amsterdam: North-Holland Publishing Company.

Duhaime, Carole and Stephen B. Ash. 1979. Satisfaction, Dissatisfaction and Complaining Behavior: A Comparison of Male and Female Consumers. In Refining Concepts and Measures of Consumer Satisfaction and Complaining Behavior, edited by H. Keith Hunt and Ralph L. Day (102-111). Bloomington, IN: Bureau of Business Research.

Fisher, James E., Dennis E. Garrett, Mark J. Arnold, and Mark E. Ferris. 1999. Dissatisfied Consumers Who Complain to the Better Business Bureau. The Journal of Consumer Marketing, 16(6): 576589.

Francken, Dick A. and W. Fred Van Raaij. 1985. Socio-Economic and Demographic Determinants of Consumer Problem Perception. Journal of Consumer Policy, 8 (September): 303-314.

Garrett, Dennis E. 2004. The Frequency and Distribution of Better Business Bureau Complaints: An Analysis Based on Exchange Transactions. Journal of Consumer Satisfaction, Dissatisfaction and Complaining Behavior, 17: 88-102.

Gronhaug, Kjell. 1987. Exploring the Problem-Prone Consumers: Hypotheses and Empirical Findings. European Journal of Marketing, 21 (1): 74-82.

Halstead, Diane, Michael A. Jones, and April N. Cox. 2007. Satisfaction Theory and the Disadvantaged Consumer. Journal of Consumer Satisfaction, Dissatisfaction and Complaining Behavior. 20: 1535.

Hogarth, Jeanne M., Maureen English, and Manisha Sharma. 2001. Consumer Complaints and Third Parties: Determinants of Consumer Satisfaction with Complaint Resolution Efforts. Journal of Consumer Satisfaction, Dissatisfaction and Complaining Behavior, 14: 74-87.

Hogarth, Jeanne M., Marianne A. Hilgert, Jane M. Kolodinsky, and Jinkook Lee. 2001. Problems With Credit Cards: An Exploration of Consumer Complaining Behaviors. Journal of Consumer Satisfaction, Dissatisfaction and Complaining Behavior, 14: 88-107.

Huefner, Jonathan C. and H. Keith Hunt. 2000. Consumer Retaliation as a Response to Dissatisfaction. Journal of Consumer Satisfaction, Dissatisfaction and Complaining Behavior, 13: 61-82.

Jae, Haeran, Devon S. Delvecchio, and Deborah Cowles. 2008. Picture-Text Incongruency in Print Advertisements Among Low- and High-Literacy Consumers. Journal of Consumer Affairs, 42 (Fall): 439-451. 
Kolodinsky, Jane. 1993. Complaints, Redress, and Subsequent Purchases of Medical Services by Dissatisfied Consumers. Journal of Consumer Policy, 16: 193-214.

Kolodinsky, Jane.. 1995. Usefulness of Economics in Explaining Consumer Complaints. Journal of Consumer Affairs, 29 (Summer): 29-54.

Kolodinsky, Jane, Meaghan Murphy, Amos Baehr, and Seth Lesser. 2005. Time Price Differentials in the Rent-to-Own Industry: Implications for Empowering Vulnerable Consumers. International Journal of Consumer Studies. 29 (March): 119-124.

Lee, Jinkook and Horacio Soberon-Ferrer. 1996. Dissatisfied Elderly Consumers: Their Behavioral Patterns and Determinants. In Marketing and Public Policy Conference Proceedings, edited by R. P. Hill and C. R. Taylor (146-153). Chicago, IL: American Marketing Association.

Liefeld, J.P., F.H.C. Edgecombe, and Linda Wolfe. 1975. Demographic Characteristics of Canadian Consumer Complainers. Journal of Consumer Affairs, 9 (Summer): 73-80.

Mansfield, Phylis M. and Mary Beth Pinto. 2008. Consumer Vulnerability and Credit Card Knowledge Among Developmentally Disabled Citizens. Journal of Consumer Affairs, 42 (Fall): 425-438.

Marlowe, Julia and Jorge H. Atiles. 2005. Consumer Fraud and Latino Immigrant Consumers in the United States. International Journal of Consumer Studies, 29 (September): 391-400.

McCormack, Lauren, Carla Bann, Jennifer Uhrig, Nancy Berkman, and Rima Rudd. 2009. Health Literacy of Older Adults. Journal of Consumer Affairs, 43 (Summer): 223-248.

Milwaukee Is Most Segregated City. U.S. Census Analysis. 2002. Jet, 26 (December): 4.

Mitra, Anu, Manoj Hastak, Gary T. Ford, and Debra Jones Ringold. 1999. Can the Educationally Disadvantaged Interpret the FDA-mandated Nutrition Facts Panel in the Presence of an Implied Health Claim? Journal of Public Policy \& Marketing, 18 (Spring): 106-117.

Morgan, Fred W. and Edward A. Riordan. 1983. The Erosion of the Unusual Susceptibility Defense: The Case of the Disadvantaged Consumer. Academy of Marketing Science, 11 (Winter/Spring): 8596.

Morgansky, Michelle Ann and Hilda Mayer Buckley. 1987. Complaint Behavior: Analysis by Demographics, Lifestyle, and Consumer Values. Advances in Consumer Research, 14: 223-226.

Moyer, Mel S. 1984. Characteristics of Consumer Complainants: Implications for Marketing and Public Policy. Journal of Public Policy \& Marketing, 3: 67-84.

Penaloza, Lisa. 1995. Immigrant Consumers: Marketing and Public Policy Considerations in the Global Economy. Journal of Public Policy \& Marketing. 14 (Fall): 83-94.

Ringold, Debra Jones. 1995. Social Criticisms of Target Marketing: Process or Product. American Behavioral Scientist, 38 (February): 578-592.

Ringold, Debra Jones.. 2005. Vulnerability in the Marketplace: Concepts, Caveats, and Possible Solutions. Journal of Macromarketing, 25 (December): 202-214.

Singh, Jagdip. 1988. Consumer Complaint Intentions and Behavior: Definitional and Taxonomical Issues. Journal of Marketing, 52 (January): 93-107.

Singh, Jagdip.. 1989. Determinants of Consumers' Decisions to Seek Third Party Redress: An Empirical Study of Dissatisfied Patients. Journal of Consumer Affairs, 23 (Winter): 329-363.

Singh, Jagdip.. 1991. Industry Characteristics and Consumer Dissatisfaction. Journal of Consumer Affairs, 25 (Summer): 19-56.

Smith, N. Craig and Elizabeth Cooper-Martin. 1997. Ethics and Target Marketing: The Role of Product Harm and Consumer Vulnerability. Journal of Marketing, 61 (July): 1-20. 
Stahle, William and Ralph L. Day. 1984. Sex Roles, Lifestyles, Store Type and Complaining Behaviors. The 8th Conference on Consumer Satisfaction, Dissatisfaction and Complaining Behavior, 59-66.

Stein, Karen F. 1980. Explaining Ghetto Consumer Behavior: Hypotheses from Urban Sociology.Journal of Consumer Affairs, 14 (Summer): 232-242.

Technical Assistance Research Programs (TARP). 1986. Consumer Complaint Handling in America: An Update Study, Part II. Washington, DC: United States Office of Consumer Affairs, March 31, contract HHS-100-84-0065.

Tipper, Ronald H. 1997. Characteristics of Consumers Who See Third Party Redress. Consumer Interests Annual, 43: 222-226.

Villareal-Camacho, Angelina. 1983. Consumer Complaining Behavior: A Cross-Cultural Comparison. In American Marketing Association Educators' Proceedings, edited by Patrick E. Murphy and Eugene R. Laczniak (68-73). Chicago: American Marketing Association.

Viswanathan, Madhubalan, Jose Antonio Rosa, and James Edwin Harris. 2005. Decision Making and Coping of Functionally Illiterate Consumers and Some Implications for Marketing Management. Journal of Marketing, 69 (January): 15-31.

Volkov, Michael, Debra Harker, and Michael Harker. 2005. Who's Complaining? Using MOSAIC to Identify the Profile of Complainants. Marketing Intelligence \& Planning, 23 (2/3): 296-312.

Ward, James C. and Amy L. Ostrom. 2006. Complaining to the Masses: The Role of Protest Framing in Customer-Created Complaint Web Sites. Journal of Consumer Research. 33 (September): 220230.

Warland, Rex H., Robert O. Herrmann, and Dan E. Moore. 1984. Consumer Complaining and Community Involvement: An Exploration of Their Theoretical and Empirical Linkages. Journal of Consumer Affairs, 18 (Summer): 64-78. 